\title{
KONDISI SOSIAL PETANI KOPI DESA UJUNG BULU, KECAMATAN RUMBIA, KABUPATEN JENEPONTO
}

\author{
SUTRISNO \\ Universitas Muhammadiyah Makassar \\ Sutrisno97@gmail.com.
}

\begin{abstract}
This study aims to determine the socio-economic conditions of Ujung Bulu Village, Rumbia District, Jeneponto Regency. This research uses descriptive quantitative research methods which are generally economic conditions viewed from economic aspects such as livelihoods, welfare and income levels. then from the social aspect seen from the level of education, health and perceptions of young people. The data source used 187 household respondents. Data were collected using a questionnaire and supported by structured interviews.The results showed that the level of income of the majority of people in Ujung Bulu Village was middle to lower, as well as the income of the agricultural sector community. The majority of Ujung Bulu Village residents work as farmers, while other sectors are mostly traders.The majority of households in Ujung Bulu Village already have a decent place to live according to some criteria and ownership status of their own building. Based on the educational background in general, Ujung Bulu Village people have a low education level with the last level of education being the elementary school level.
\end{abstract}

Keywords: Socio-Economic Conditions, Farming, Income, Education Level, Welfare

\begin{abstract}
Abstrak
Penelitian ini bertujuan untuk mengetahui kondisi sosial ekonomi Desa Ujung Bulu, Kecamatan Rumbia, Kabupaten Jeneponto.Penelitian ini menggunakan metode penelitian kuantitatif deskriptif yang umumnya kondisi ekonomi dilihat dari aspek ekonomi seperti mata pencaharian, kesejahteraan dan tingkat pendapatan.kemudian dari aspek sosial dilihat dari tingkat pendidikan, kesehatan dan persepsi anak muda. Sumber data menggunakan 187 responden rumah tangga.Data dikumpulkan menggunakan kuesioner dan didukung oleh wawancara terstruktur.Hasil penelitian menunjukkan bahwa tingkat pendapatan sebagian besar orang di Desa Ujung Bulu adalah menengah ke bawah, serta pendapatan masyarakat sektor pertanian.Mayoritas penduduk Desa Ujung Bulu bekerja sebagai petani, sementara sektor lainnya kebanyakan adalah pedagang.Mayoritas rumah tangga di Desa Ujung Bulu telah memiliki tempat tinggal yang layak sesuai dengan beberapa kriteria dan status kepemilikan bangunan mereka
\end{abstract}


sendiri.Berdasarkan latar belakang pendidikan secara umum, masyarakat Desa Ujung Bulu memiliki tingkat pendidikan yang rendah dengan tingkat pendidikan terakhir adalah tingkat sekolah dasar.

Kata kunci: Kondisi Sosial Ekonomi, Pertanian, Penghasilan, Tingkat Pendidikan, Kesejahteraan

\section{PENDAHULUAN}

Kabupaten Jeneponto merupakan salah satu daerah tingkat II di Provinsi Sulawesi Selatan, Indonesia. Kabupaten Jeneponto memiliki luas wilayah sebesar $749,79 \mathrm{~km}^{2}$ dengan jumlah penduduk sekitar 330.735 jiwa. Dikalangan masyarakat umum Jeneponto dikenal sebagai daerah yang gersang dan kering. Namun, pendapat seperti ini tidak sepenuhnya benar karena terdapat beberapa wilayah di Kabupaten Jeneponto justru memiliki ketinggian antara 600-1900 meter diatas permukaan laut (mdpl), salah satunya adalah Desa Ujung Bulu yang terletak pada ketinggian 1400 mdpl. Desa Ujung Bulu merupakan daerah administratif Kecamatan Rumbia, Kabupaten Jeneponto.

Jika dibandingkan dengan Kabupaten lain di Sulawesi Selatan, Kabupaten Jeneponto memiliki luas wilayah terkecil ke-7. Dari sudut pandang astronomis Kabupaten Jeneponto terletak diantara 5'23'12"-5'42'12" Lintang Selatan dan 119²9'12"-11956'44" Bujur Timur. Kabupaten Jeneponto berbatasan langsung dengan tiga kabupaten lain di Sulawesi Selatan yaitu Kabupaten Bantaeng di sebelah timur, Kabupaten Gowa disebelah utara, dan Kabupaten Takalar di sebelah barat. Sementara di Bagian selatan Kabupaten Jeneponto terdapat Selat Flores. Ibu kota Kabupaten ini berada di Bonto Sunggu, Kelurahan Empoang, Kecamatan Binamu. Kecamatan yang memiliki wilayah paling luas adalah Kecamatan Bangkala dengan luas 152,96 km².

Sektor pertanian masih menjadi sektor dominasi di Kabupaten Jeneponto.Sebagian besar wilayah Kabupaten Jeneponto merupakan lahan pertanian, dengan luas 64,397 ha atau sekitar 85,89\% dari daerah tersebut. Akan tetapi, pada tahun 2015 luas lahan pertanian di Kabupaten ini mengalami 
penyempitan sekitar $27,91 \%$ dari tahun sebelumnya. ${ }^{1}$ Salah satu desa di Kabupaten Jeneponto yang memiliki sumber daya alam yang paling potensial dalam pengambangan sektor pertanian, terutama pengembangan agribisnis kopi adalah Desa Ujung Bulu.

Desa Ujung Bulu merupakan wilayah administratif Kabupaten Jeneponto yang berada pada ketimggian 1400 dengan kualitas tanah yang cukup subur dan curah hujan $1535 \mathrm{~mm}$. Desa Ujung Bulu berada di dataran tinggi yang didominasi oleh lahan pertanian dan perkebunan yang sangat luas, serta memiliki potensi sumberdaya alam yang sanagat kaya, seperti sumber mata air yang dapat ditemukan di setiap dusun, sehingga di lahan pertanian milik warga dapat ditemui berbagai jenis tanaman hortikultura dan tanaman perkebunan terutama kopi.

Namun berbanding terbalik dengan potensi sumber daya alam khususnya di bidang pertanian yang dimilikinya, Kabupaten Jeneponto justru termasuk dalam kategori kabupaten/daerah teringgal di Provinsi Sulawesi Selatan.Salah satu penyebab dari fenomena tersebut adalah ketidakmampuan daerah dalam mengelola potensi sumber daya di sektor pertanian yang berdampak pada kemerosotan perekonomian wilayah. Inilah yang terjadi di daerah tertinggal di Indonesia.Salah satu faktor utama yang menyebabkan ketidakmampuan daerah dalam mengelola potensi sumber daya dibidang pertanian adalah tidak konsistennya perencanaan pembangunan di sektor pertanian. Ketidak jelasan arah pembangunan pertanian karena tidak di dukung oleh data yang akurat terkait potensi wilayah yang digunakan dalam perencanaan wilayah sehingga akan berdampak pada berubahnya kebijakan arah pembangunan pertanian dari masa ke masa. $^{2}$

Pembangunan pertanian di Indonesia selama ini hanya melibatkan kajian teori hubungan antar berbagai variabel yang saling berhubungan satu sama lain seperti, ekonomi, sosial, budaya, kebijakan, infrastruktur dan jaringan, namun belum sepenuhnya melibatkan ruang dan waktu, sehingga perencanaan

\footnotetext{
${ }^{1}$ Badan Pusat Statistik (BPS). Jeneponto Dalam Angka 2017. Katalog BPS 1102001.1375 diaksesdari http://www.bps.go.id/, diakses pada tanggal 17 Mei 2018 pada jam 19.37 WIB.

${ }^{2}$ Isnam Junais, dkk., Integrasi Pendekatan Sosio-Spasial dalam Perencanaan Penggunaan Lahan Untuk Komoditas Agribisnis: Studi Kasus Kabupaten Tertinggal di Sulawesi Selatan, Indonesia, 2019), h. 2.
} 
pembangunan pertanian dalam praktinya mengalami ketidakseimbangan. Pengelolaan sumber daya manusia dan sumber daya alam perlu memperhitungkan perspektif spasial, sehingga dalam rangkaian menyeluruh dapat dibuatkan pengikat antar objek dalam dimensi yang berbeda. Pola integrasi sosio spasial dalam pembangunan pertanian sangat diperlukan dalam mengurai berbagai macam kompleksitas permasalahan dan kesenjangan yang terjadi.Pendekatan sosio spasial dinilai mampu bekerja secara kompleks dan bersinergi dengan pendekatan yang berbeda. ${ }^{3}$

Sistem dan usaha agribisnis merupakan sektor yang paling ideal dalam mendongkrak perekonomian masyarakat di Desa Ujung Bulu. Agribisnis mampu menjadi basis pengembangan ekonomi nasional karena mampu mengakomodasi pertumbuhan perekonomian suatu daerah. ${ }^{4}$ Dengan prinsip kerakyatan, pemerataan dan berkelanjutan baik antar individu, kelompok maupun daerah, agribisnis akan mampu manjadi tulang punggung pengembanagan ekonomi suatu daerah. Oleh karena itu penelitian ini akan mengkaji tentang kondisi sosial ekonomi masyarakat yang selanjutnya dimodelkan secara spasial sebagai acuan untuk pengembangan agribisnis kopi dengan hasil akhir peta kondisi sosial ekonomi di Desa Ujung Bulu. Peta tersebut digunakan sebagai alat untuk mengolah dan menganalisis kondisi sosial ekonomi masyarakat pada kawasan Desa Ujung Bulu sehingga dapat diketahui strategi pengembangan agribisnis yang tepat sesuai dengan variabel yang ada.Dari latar belakang yang telah diuraikan, maka perlu diketahui lebih dalam kondisi sosial dan kondisi ekonomi petani kopi Desa Ujung Bulu, Kecamatan Rumbia, Kabupaten Jeneponto.

\section{TINJAUAN PUSTAKA}

\section{Sosiologi Ekonomi}

Definisi Sosiologi Ekonomi dapat dilihat dari dua sudut pandang.Pertama, sosiologi ekonomi sebagai sebuah kajian yang mempelejari hubungan antar

\footnotetext{
${ }^{3}$ Isnam Junais, dkk., Integrasi Pendekatan Sosio-Spasial dalam Perencanaan Penggunaan Lahan Untuk Komoditas Agribisnis: Studi Kasus Kabupaten Tertinggal di Sulawesi Selatan, Indonesia, h.3.

${ }^{4}$ Bungaran Saragih, Suara dari Bogor: Membangun Sistem Agribisnis. (Bogor: Yayasan USESE 2001), h. 83.
} 
masyarakat yang didalamnya terdapat interaksi sosial dengan ekonomi, sehingga dapat dilihat bagaimana masyarakat mempengaruhi ekonomi.Sudut pandang yang kedua yaitu, bagaimana ekonomi mempengaruhi masyarakat, pada sudut pandang ini sosiologi ekonomi mengkaji masyarakat yang didalamnya terdapat interaksi sosial, dalam hubungannya dengan ekonomi. Hubungan ini dilihat dari perspektif saling pengaruh mempengaruhi masyarakat sebagai suatu realitas-objektif yang menuntun indidvidu dalam melakukan aktivitas ekonomi, seperti apa yang boleh diproduksi, apa yang harus diproduksi, bagaimana memproduksinya, dan dimana memproduksinya. ${ }^{5}$

\section{Konsep Ruang dan Wilayah}

Dalam Undang-undang No. 24 tahun 1992 tentang Penataan Ruang (UUTR) pengertian "ruang" meliputi ruang daratan, ruang lautan dan ruang udara beserta sumberdaya yang terkandung didalamnya. Ruang yang dimaksud dalam sistem tata ruang, secara alamiah adalah biosphere yang terdiri dari sebagian geosphere (permukaan kulit bumi hingga kedalaman 3m di dalam tanah dan 200m dibawah permukaan laut) dan sebagian dari atmosphere kira 30m diatas permukaan tanah. ${ }^{6}$

Dalam istilah geografi ruang diartikan sebagai seluruh permukaan bumi yang merupakan lapisan biosphere, tempat hidup umbuh-tumbuhan hewan dan manusia. Sementara geografi regional mendefinisikan ruang sebagai suatu wilayah yang mempunyai batas geografi berdasarkan keadaan fisik, sosial atau pemerintahan yang terdapat pada sebagian permukaan bumi dan lapisan bawahnya serta lapisan udara diatasnya. ${ }^{7}$

\section{Pemetaan Sosial Ekonomi}

Menurut Laurence pendekatan ekonomi baik klasik maupun neo-klasik tidak cukup untuk menjawab semua masalah ekonomi, sehingga dibutuhkan

\footnotetext{
2009), h. 21.

${ }^{5}$ Damsar dan Indriani, Pengantar Sosiologi Ekonomi (Jakarta: PT. Kharisma Utama,

${ }^{6}$ Rudito, Bambang dan Melia Famiola, Social Mapping: Metode Pemetaan Sosial Teknik Memahami Suatu Masyarakat atau Komuniti (Bandung: Rekayasa Sains, 2008), h. 38.

${ }^{7}$ J,T. Jayadinata, Tata Guna Tanah Dalam Perencanaan Pedesaan, Perkotaan dan Wilayah (Edisi ke-3; Bandung: ITB, 1999), h. 98.
} 
penggunaan perspektif yang lebih luas, seperti penggunaan sosiologi, psikologi dan geografi serta ilmu sosial lainnya. ${ }^{8}$

Pada dasarnya pemetaan didefinisikan sebagai suatu istilah generik yang mendeskripsikan sejumlah proses dengan tujuan untuk merepresentasikan ide-ide secara visual dalam bentuk gambar atau peta (Kane dan Wiliam, 2007). Dalam Permen PU No. 05,PRT/M/2013 tentang Pedoman Pemetaan Sosial Ekonomi dan Lingkungan Bidang Pekerjaan Umum dijelaskan lebih rinci mengenai pemetaan. Dalam pedoman tersebut dijelaskan bahwa pemetaan adalah proses penggambaran kondisi dan potensi sosial lingkungan suatu wilayah secara sistematis untuk menyediakan data dan informasi yang dibutuhkan dalam setiap tahapan pembangunan pekerjaan umum. Dalam sudut pandang sosial, pemetaan sosial diartikan sebagai suatu proses penggambaran kondisi masyarakat secara sistemik yang melibatkan pengumpulan data dan informasi mengenai masyarakat yang didalamnya terdapat profil beserta kondisi sosial yang ada pada masyarakat. ${ }^{9}$ Menurut Rudito dan Melia, pengumpulan data dan informasi pada pemetaan sosial dapat menggunakan existing data approach, attitude data approach, key informan approach, community forum, dan focus group discussion (FGD). ${ }^{10}$

Pemetaan sosial merupakan suatu upaya untuk mengidentifikasi dan memahami struktur sosial sistem kelembagaan dan individu, serta tata hubungan antar kelompok atau individu didalam suatu lingkungan sosial tertentu. ${ }^{11}$ Peta yang baik dapat difungsikan sebagai dasar dari kebijakan dan strategi yang secara positif dapat membangun relasi yang saling mendukung dan menghubungkan satu sama lain. ${ }^{12}$

Dalam konteks ekonomi, pemetaan ekonomi adalah pemetaan yang mendeskripsikan aktivitas ekonomi yang dilakukan oleh masyarakat suatu wilayah, baik yang bersifat makro maupun mikro.Sementara itu, pemetaan

\footnotetext{
${ }^{8}$ Damsar dan Indriani, Pengantar Sosiologi Ekonomi, h. 23.

${ }^{9}$ Edy Suharto, Membangun Masyarakat Memberdayakan Rakyat: Kajian Strategis Pembangunan Kesejahteraan Sosial dan Pekerjaan Sosial. Bandung: PT Refika Aditama, 2005.

${ }^{10}$ Rudito, Bambang dan Melia Famiola, Social Mapping: Metode Pemetaan Sosial Teknik Memahami Suatu Masyarakat atau Komuniti, h. 40.

${ }^{11}$ DodyPrayogo, "Pemetaan Sosial Mengenai Hubungan Korporasi-Komunitas Lokal" Dalam Masyarakat Jurnal Sosiologi. (Edisi No. 12; Depok: Labsosio FISIP-UI, 2003), h. 14.

12 DodyPrayogo, "Pemetaan Sosial Mengenai Hubungan Korporasi-Komunitas Lokal" Dalam Masyarakat Jurnal Sosiologi. (Edisi No. 12; Depok: Labsosio FISIP-UI, 2003), h. 14.
} 
lingkungan lebih banyak diarahkan untuk kondisi lingkungan alam, sosial, dan binaan yang dalam suatu kawasan tertentu.

\section{Agribisnis}

Secara etimologi, kata agribisnis terbentuk dari dua unsur kata yaitu "agri" yang berasal dari kata Agriculture yang berarti pertanian dan "bisnis" yang berarti usaha, sehingga agribisnis dapat dipahami sebagai suatu sistem usaha dalam bidang pertanian yang mencakup proses pengolahan, pemasaran dan kegiatan lain yang berkaitan. ${ }^{13}$

Agribisnis melingkupi subsistem sarana produksi atau bahan baku hulu, proses produksi biologis pada tingkat bisnis dan usahatani. Agribisnis mencakup proses produksi, konsumsi dan distribusi serta subsistem lain seperti pemodalan, jasa, dan perbankan. Seluruh aktivitas usahatani dalam agribisnis merupakan satu kesatuan yang apabila di pilah-pilah dalam suatu satuan terpisah akan berpotensi menimbulkan gangguan pada seluruh rangkaian yang ada dan tidak menutup kemungkinan menimbulkan permasalahan pada tingkatan berikutnya yang lebih serius. $^{14}$

Pembangunan agribisnis memerlukan perhatian yang secara integral dilakukan pada setiap subsistem dengan mengutamakan hal-hal yang dapat lebih muda diadopsi oleh para pelaku. Agar para pelaku tidak lagi menerjemahkan agribisnis sebagai sesuatu yang sifatnya eksklusif dan memiliki privilis tertentu.

Seiring dengan berjalannya waktu perubahan pembangunan sistem dan usaha agribisnis terus mengalami perubahan. Pembangunan agribisnis tidak lagi bersifat sentralistik dan top down saja, sebagaimana yang terjadi dimasa lalu.Sekarang pengembangan agribisnis dilaksanakan dengan desentralisasi dengan mengedepankan kreativitas pelaku agribisnis di daerah, agar sistem usaha agribisnis dapat bersaing, berkerakyatan dan berkelanjutan. ${ }^{15}$

\footnotetext{
${ }^{13}$ Soekartawi, Agribisnis Teori dan Aplikasinya (Jakarta: Raja Garfindo Persada, 1993.), h.38.

${ }^{14}$ Bustanul Arifin, Refleksi dan Perkembangan Agribisnis di Indonesia. Jurnal Agrimedia, Institut Pertanian Bogor; Vol.4; Bogor: IPB, 2004, h.12. USESE, 2001

${ }^{15}$ Bungaran Saragih, Suara dari Bogor: Membangun Sistem Agribisnis (Bogor: Yayasan
} 
Strategi pengembangan agribisnis tidak hanya melibatkan persoalan manajemen bisnis di tingkat mikro, akan tetapi agribisnis juga melibatkan kebijakan di tingkat makro serta kemampuan untuk mensiasati dan menemukan srategi di tingkat usahatani. Agribisnis sangat memerlukan perpaduan formasi makro-mikro ini, mengingat agribisnis merupakan suatu rangkaian sistem usaha yang berbasis pertanian dan sumberdaya dari hulu hingga hilir. ${ }^{16}$

\section{Komoditas Kopi Indonesia}

Kopi (Coffea sp) merupakan spesies tanaman tang tergabung dalam famili Rubiaciae yang merupakan salah satu bagian dari genus Coffea. Tanaman ini dapat tumbuh dengan tinggi mencapai $12 \mathrm{~m}$. berdasarkan ciri-ciri fisiknya kopi memiliki bentuk daun bulat telur dengan ujung daun yang runcing. Bentuk percabangan dari kopi agak berbeda dengan tanaman yang lain.

Kopi dapat tumbuh secara optimal jika berada pada zona terbaik pertumbuhannya, yaitu antara 200 LU dan 100 LU. Di Indonesia, sebagian besar daerah penghasil kopi berada pada letak geografis antara 0-100 LS yaitu Sumatera Selatan, Lampung, Bali, Sulawesi Selatan dan sebagian kecil berada diantara 0-50 LU yaitu Aceh dan Sumater Utara. Unsur iklim yang banyak berpengaruh terhadap budidaya kopi adalah ketinggian (elevasi), tempratur dan curah hujan.

Tanah merupakan syarat yang ideal untuk pertumbuhan tanaman kopi, hal ini agar air dapat mengalir ke dalam tanah secara bebas. Tanaman kopi tidak terlalu cocok tumbuh ditanah liat yang terlalu lekat karena memiliki memiliki pori yang kecil sehingga menahan terlalu banyak air pada permukaan tanah.

Kopi sudah sangat lama di budidayakan dan memiliki nilai ekonomis yang cukup tinggi.Konsumsi kopi dunia mencapai $70 \%$ berasal dari kopi arabika sementara $26 \%$ adalah kopi robusta.Menurut sejarah, kopi berasal dari pegunungan etopia, salah satu negara di Benua Afrika. Akan tetapi kopi baru menjadi popular dikalangan masyarakat dunia setelah dikembangkan di daerah Yaman di selatan Arab oleh para saudagar Yaman. ${ }^{17}$.

\footnotetext{
${ }^{16}$ Bustanul Arifin, Refleksi dan Perkembangan Agribisnis di Indonesia, h. 13.

${ }^{17}$ PudjiRahardjo,Panduan Budidaya dan Pengolahan Kopi Arabika dan Robusta (Jakarta: Penebar Swadaya: 2012), h. 21.
} 


\section{Keterlekatan Perilaku Ekonomi Dalam Hubungan Sosial}

Menurut Granovetter, keterlekatan merupakan tindakan ekonomi yang melekat dan disituasikan secara sosial dalam suatu jaringan sosial. Keterlekatan tidak hanya menyangkut persoalan tindakan aktor individual, melainkan mencakup perilaku ekonomi yang lebih luas, seperti penetapan harga dan institusi ekonomi. Hal ini disebabkan Karena baik harga maupun institusi ekonomi yang ada sama-sama terpendam dalam suatu jaringan hubungan sosial. Yang dimaksud dengan jaringan sosial adalah hubungan sosial yang sama diantara individu atau kelompok. ${ }^{18}$ Tindakan yang dilakukan oleh jaringan adalah terlekat karena diekspresikan melalui interaksi dengan orang lain. Keterlekatan seseoorang dalam jaringan sosial akan menentukan banyaknya tindakan sosial seseorang dan jumlah dari hasil institusional.

\section{METODE PENELITIAN}

\section{Lokasi dan Waktu Penelitian}

Lokasi penelitian adalah tempat atau wilayah dimana suatu penelitian akan dilakukan. Adapun penelitian yang dilakukan oleh penulis mengambil lokasi di Desa Ujung Bulu, Kecamatan Rumbia, Kabupaten Jeneponto. Waktu yang digunakan dalam penelitian ini selama bulan Mei-Juli 2019.

Gambar 2. Peta Lokasi Penelitian
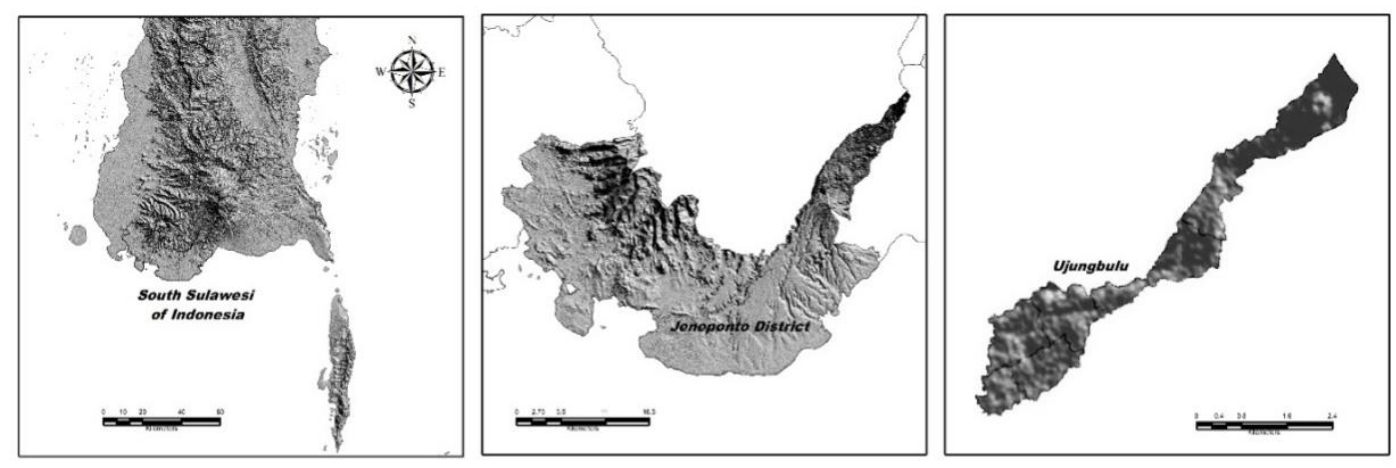

${ }^{18}$ Damsar dan Indriani, Pengantar Sosiologi Ekonomi, h. 26. 


\section{Teknik Penentuan Sampel/Informan}

Populasi adalah wilayah generalisasi yang terdiri atas objek/subjek dengan kualitas dan karakteristik tertentu yang ditetapkan oleh peneliti sebagai bahan pembelajaran untuk kemudian ditarik kesimpulan (Sugiyono 2010).Sedangkan, sampel merupakan sebagian dari jumlah dan karakteristik yang dimiliki oleh suatu populasi. ${ }^{19}$

Cluster Sampling merupakan teknik sampling yang digunakan untuk membangun data kewilayahan dalam menyusun pemetaan yang melibatkan data yang cukup luas. Teknik sampling ini digunakan melalui dua tahap, yaitu yang pertama menentukan klaster daerah lokasi sampling dan yang kedua adalah menentukan sampling variabel/orang dalam setiap klaster wilayah, dalam penentuan variabel dapat dilakukan dengan simple ramdom sampling yaitu dengan memilih responden secara acak di setiap wilayah.

Dari pengertian populasi di atas bahwa merupakan objek dan subjek yang berada pada suatu wilayah dengan syarat-syarat tertentu dan memenuhi syarat tersebut dalam kaitannya dengan masalah dalam penelitian maka yang menjadi populasi sasaran dalam penelitian adalah masyarakat Desa Ujung Bulu yang berprofesi sebagai petani yaitu sebanyak 816 orang. ${ }^{20}$ Populasi ini kemudian dibagi menjadi 7 klaster wilayah berdasarkan jumlah dusun yang ada, selanjutnya ditentukan sampel yang digunakan dalam penelitian ini diambil berdasarkan Tabel penentuan sampel menurut Isaac \& Michael dengan tingkat kesalahan 5\% yaitu sebanyak 243 orang petani kemudian dibagi berdasarkan jumlah klaster yang ada yaitu 40 orang tiap klasternya, sistem pengambilan sampel dilakukan dengan Simple Random Sampling. ${ }^{21}$

${ }^{19}$ Sugiyono, Metode Penelitian Pendidikan Pendekatan Kuantitatif, Kualitatif dan $R \& B$ (Bandung: Alfabeta. 2010), h. 45.

${ }^{20}$ RPJM Desa Ujung Bulu, Rencana Pembangunan Jangka Menengah Tahun 2016-2021 Kabupaten Jeneponto. 2016).

${ }^{21}$ Sugiyono, Metode Penelitian Pendidikan Pendekatan Kuantitatif, Kualitatif dan R\&B (Bandung: Alfabeta. 2010), h. 58. 


\section{Sumber Data}

Sumber data dalam penelitian adalah subjek darimana data dapat diperoleh, dalam penelitian ini penulis menggunakan sumber data primer dan sekunder. Sumber data primer adalah data yang dikumpulkan secara langsung oleh peneliti dari sumber pertamanya. Sedangkan sumber data sekunder adalah data yang dikumpulkan oleh peneliti sebagai penunjang data pimer. Data sekunder juga biasa disebut sebagai data yang tersusun dalam bentuk dokumen-dokumen.

\section{Teknik Pengumpulan Data}

Teknik pengumpulan data dalam penelitian ini dapat diuraikan sebagai berikut (1) Observasi, yaitu teknik pengumpulan data dengan cara mengamati dan mencatat gejala-gejala yang diamati secara sistematik. (2) Wawancara, yaitu pengumpulan data dengan cara memberikan sejumlah pertanyaan lisan yang dijawab secara lisan pula oleh responden. (3) Kuesioner, yaitu sejumlah pertanyaan tertulis yang harus dijawab secara tertulis oleh responden. (4) Dokumentasi, yaitu sumber data yang digunakan sebagai pelengkap penelitian dimana data yang diperoleh berasal dariarsip atau dokumentasi di lokasi penelitian.

\section{Teknik Analisis Data}

Data primer dan data sekunder yang diperoleh akan diolah dan dianalasis dengan tujuan untuk memperoleh suatu kesimpulan. Kemudian untuk memperoleh pemahaman yang jelas dan terarah dari hasil penelitian maka data disajikan secara deskriptif.

Analisis deskriptif adalah analisis data dengan menjelaskan, menguraikan dan menggambarkan suatu permasalahan yang erat kaitannya dengan penelitian ini. Hasil penelitian akan menggambarkan kondisi sosial ekonomi petani kopi di lokasi penelitian dari beberapa sampel/informan.

Penelitian ini dilaksanakan dengan metode survey deskriptif. Metode penelitian deskriptif bertujuan untuk mengetahui variabel mandiri atau lebih (independen) tanpa perbandingan atau penggabungan antara suatu variabel dengan variable 
yang lain. ${ }^{22}$ Untuk melihat variabel pengaruh maka digunakan skala likert. Skala likert merupakan analisis yang digunakan untuk mengukur variabel yang hanya bisa dijawab dengan kata verbal seperti persepsi, sikap dan pendapat seseorang tentang suatu fenomena social. ${ }^{23}$ Untuk setiap pilihan di berikan skor, maka responden harus menggambarkan penyataan tersebut. Dengan skala likert, maka variabel yang digunakan akan diukur dan dijabarkan menjadi indikator variabel. Kemudian indikaor tersebut dijadikan sebagai acuan dalam menyusun item-item instrumen yang berupa pertanyaan atau pernyataan.

Tabel 1.Tabel Skala Penilaian Untuk Pernyataan Positif atau Negatif.

\begin{tabular}{|l|l|l|l|}
\hline No & Keterangan & $\begin{array}{l}\text { Skor } \\
\text { Positif }\end{array}$ & $\begin{array}{l}\text { Skor } \\
\text { Negatif }\end{array}$ \\
\hline 1 & Sangat Setuju & 5 & 1 \\
\hline 2 & Setuju & 4 & 2 \\
\hline 3 & Ragu-ragu & 3 & 3 \\
\hline 4 & Tidak Setuju & 2 & 4 \\
\hline 5 & Sangat Tidak setuju & 1 & 5 \\
\hline
\end{tabular}

Sumber: Sugiyono (2010).

IUntuk menentukan batas skala skor dapat digunakan rumus yaitu :

$$
\frac{\text { Nilai Maksimum - Nilai Minimum }}{\text { Skala/Rentang }}
$$

Analisis Spasial digunakan untuk membangun gambaran kondisi sosial ekonomi berdasarkan struktur geografis dengan melibatkan unsur perspektif dalam geografi yang mencoba memahami proses pembentukan dan evolusi bentang lahan dan tempat (places) dengan referensi prinsip-prinsip universal dan general. Hasil Analisis spasial akan memproyeksikan kondisi sosial ekonomi. Analisis spasial dan penyajian hasil dilakukan dengan pendekatan Sistem Informasi Geografis (SIG) dengan menggunakan software utama ArcGIS.

\footnotetext{
${ }^{22}$ Sugiyono, Metode Penelitian Pendidikan Pendekatan Kuantitatif, Kualitatif dan $R \& B$ (Bandung: Alfabeta. 2010), h. 67.

${ }^{23}$ Sugiyono, Metode Penelitian Pendidikan Pendekatan Kuantitatif, Kualitatif dan R\&B (Bandung: Alfabeta. 2010), h. 45.
} 
Gambar 3.

Diagram Proses Pembuatan Peta-peta Tematik.

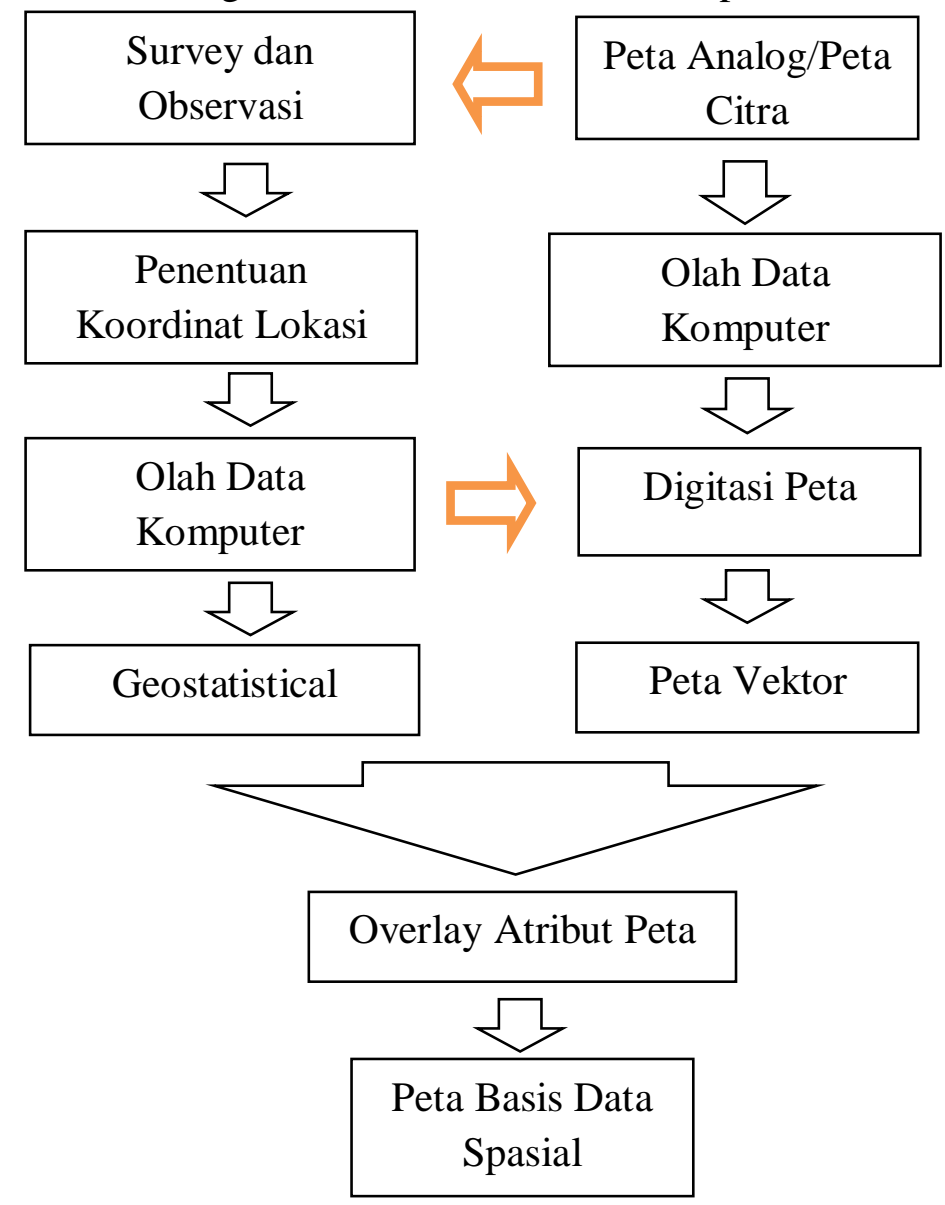

\section{HASIL DAN PEMBAHASAN}

\section{Identitas Responden}

Umur dapat menentukan prestasi kerja atau kinerja seseorang.Potensi umur petani menjadi tolak ukur kemampuan seseorang dalam melaksanakan suatu aktivitas. Umur petani sangat mempengaruhi kemampuan bekerja dan cara berpikir, sehingga secara langsung akan berpengaruh terhadap pengelolaan usahataninya. Semakin Berat pekerjaan dan semakin tua umur tenaga kerja akan berakibat pada menurunnnya produktivitas. Namun, dalam hal tanggungan keluarga hal ini tidak memiliki pengaruh yang siginifikan karena semakin tua usia petani maka ia akan semakin berpengalaman dalam prses usahatani selain usia petani, pendidikan petani serta susunan dan besarnya anggota keluarga petani juga berpengaruh terhadap produktiviats petani. 
Tabel 7.

Klasifikasi Petani Responden Berdasarkan Usia di Desa Ujung Bulu Kecamatan Rumbia Kabupaten Jeneponto.

\begin{tabular}{|c|c|c|c|}
\hline No. & Umur Responden & $\begin{array}{c}\text { Jumlah } \\
\text { (Orang) }\end{array}$ & $\begin{array}{c}\text { Persentase } \\
(\boldsymbol{\%})\end{array}$ \\
\hline 1. & $15-20$ & 4 & 2 \\
2. & $21-30$ & 33 & 18 \\
3. & $31-40$ & 51 & 27 \\
4. & $41-50$ & 45 & 24 \\
5. & $51-60$ & 34 & 18 \\
6. & 61 keatas & 20 & 11 \\
\cline { 2 - 4 } & Total & $\mathbf{1 8 7}$ & $\mathbf{1 0 0}$ \\
\hline
\end{tabular}

Sumber: Data primer setelah diolah.

Pada tabel 4 dijelaskan bahwa jumlah responden yang terbanyak adalah golongan usia 31-40 tahun yaitu sebanyak 51orang ini berarti bahwa golongan usia responden tergolong produktif dan yang paling sedikit adalah golongan usia 15-40 tahun sebanyak 4 orang. Petani yang berumur produktif mempunyai kemampuan fisik yang lebih baik dan lebih giat dalam mengadopsi tekhnolgi dan informasi dibandingkan dengan petani yang berumur tua, namun petani yang berumur tua mempunyai pengalaman yang jauh lebih banyak dibanding lebih muda sehingga lebih matang dalam mengelolah usahataninya dan lebih berhatihati dalam menghadapi tekhnologi dan informasi. Kematangan umur akan berpengaruh terhadap pola pikir dan perilaku baik formal dan nonformal.

\section{Jumlah Tanggungan Keluarga}

Tanggungan keluarga merupakan total keseluruhan anggota keluarga yang pemenuhan kebutuhan hidupnya bergantung pada kepala keluarg. Kepala keluarga kepala keluarga berperan sebagai penanggung jawab segala kegiatan yang ada dalam rumah tangga serta berusaha untuk selalu memenuhi kebutuhan dari semua anggota keluarga yang menjadi tanggungannya. Jumlah tanggungan keluarga berpengaruh terhadap etos kerja dari kepala keluarga hal ini disebabkan besaran pendapatan yang harus dicapai akan meningkat seiring dengan peningkatan jumah tanggungan keluarga agar kebutuhan keluarga dapat terpenuhi. Biasanya petani yang memiliki jumlah tanggungan keluarga yang banyak akanlebih giat berusaha 
dalam rangka pengembangan usahataninya demi kebutuhan hidup keluarganya karena kebutuhan keluarga selalu meningkat.

Jumlah tanggungan keluarga responden di daerah penelitian berkisar antara 13 orang dan 4-6 orang. Untuk lebih jelasnya rata-rata jumlah tanggungan keluarga dapat dilihat pada tabel berikut:

Tabel 8.

Klasifikasi Petani Responden Berdasarkan Jumlah Tanggungan Keluarga

\begin{tabular}{|l|l|l|l|}
\hline No. & $\begin{array}{l}\text { Tanggungan Keluarga } \\
(\text { orang) }\end{array}$ & $\begin{array}{l}\text { Jumlah } \\
\text { (orang) }\end{array}$ & $\begin{array}{l}\text { Persentase } \\
(\%)\end{array}$ \\
\hline 1. & $1-3$ & 166 & 89 \\
\hline 2. & $4-6$ & 21 & 11 \\
\hline Total & $\mathbf{1 8 7}$ & $\mathbf{1 0 0}$ \\
\hline
\end{tabular}

Sumber: Data primer setelah diolah.

\section{Kondisi Sosial}

\section{Umur}

Jumlah tenaga kerja usaha tani di Desa Ujung Bulu' berdasar umur berasal dari kelompok umur kurang dari 30 tahun yakni sebanyak 253orang,sedangkan pada kelompok umur diatas 60tahun sebanyak 35 orang (Tabel 9).

Tabel 9

Tenaga kerja usahatani berdasarkan kelompok umur di

Desa Ujung Bulu

\begin{tabular}{|l|l|l|l|}
\hline No. & Umur & $\begin{array}{l}\text { Jumlah } \\
\text { (orang) }\end{array}$ & Persen (\%) \\
\hline 1 & Muda $\leq 30$ & 253 & 46 \\
\hline 2 & Sedang $31-60$ & 266 & 48 \\
\hline 3 & Tua $60 \geq$ & 35 & 6 \\
\hline \multicolumn{2}{l}{ Total } & $\mathbf{5 5 4}$ & $\mathbf{1 0 0}$ \\
\hline
\end{tabular}

Sumber: Data primer setelah diolah.

Sekitar $46 \%$ tenaga kerja usaha tani di Desa Ujung Bulu' merupakan petani produktif dengan umur antara 31-60 tahun. Sisanya sekitar 6\% merupakan petani dengan kisaran umur lebih dari 60 tahun yang termasuk dalam kategori tidak produktif.Petani umur 31-60 tahun memiliki fisik yang lebih mendukung kegiatan usahatani, lebih dinamis dan kreatif serta cenderung mudah dalam mengadopsi inovasi teknologi baru.Petani berumur lebih dari 60 tahun memiliki kelebihan 
dalam hal pengalaman, pertimbangan, etika kerja dan komitmen terhadap mutu. Kekurangan dari petani dengan umur lebih dari 60 tahun adalah sering dianggap kurang luwes dan menolak teknologi baru.

Gambar 4.

Peta informasi spasial umur petani kopi Desa Ujung Bulu.

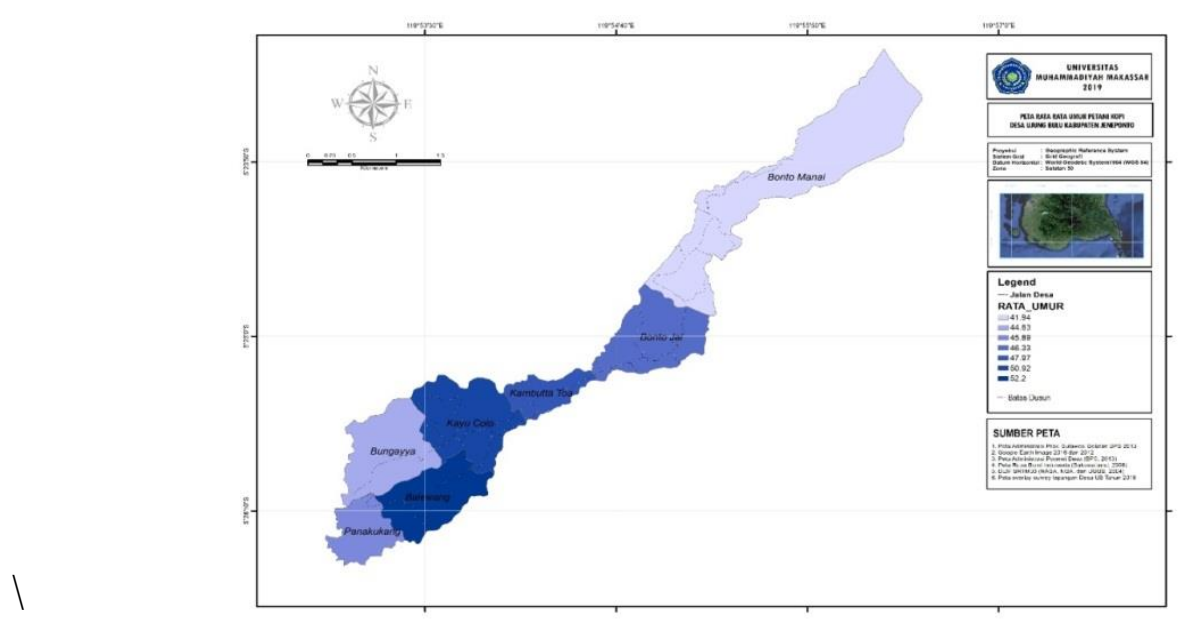

Pada gambar diatas dapat dilihat bahwa rata-rata umur petani kopi pada dusun di Desa Ujung Bulu masih di dominasi oleh petani kopi dengan kategori usia produktif. Umur petani kopi di Dusun Bonto Manai adalah 41 tahun.Di Dusun Bonto Jai petani kopi memiliki umur rata-rata 44 tahun.Di Dusun Kambutta Toa rata-rata umur petani kopi adalah 47 tahun. Umur Petani di Dusun Kayu coloadalah rata-rata 50 tahun. Di Dusun Balewang rata-rata umur petani kopi52 tahun.Di Dusun Bungaya rata-rata umur petani kopi 45 tahun.Di Dusun Panakukang rata-rata umur petani kopi 46 tahun.

\section{Tingkat Pendidikan}

Pendidikan seseorang pada umumnya akanmempengaruhi cara berpikirnya. Denganpendidikan maka seseorang akan memilikipengetahuan yang luas, mudah mengembangkanide-ide, mudah mengadopsi teknologi dan makin dinamis sikapnya terhadap hal-hal baru terutamadalam menghadapi perubahan yang lebih modern. 
Gambar 5.

Tingkat pendidikan tenaga kerja usaha tani Desa Ujung Bulu.

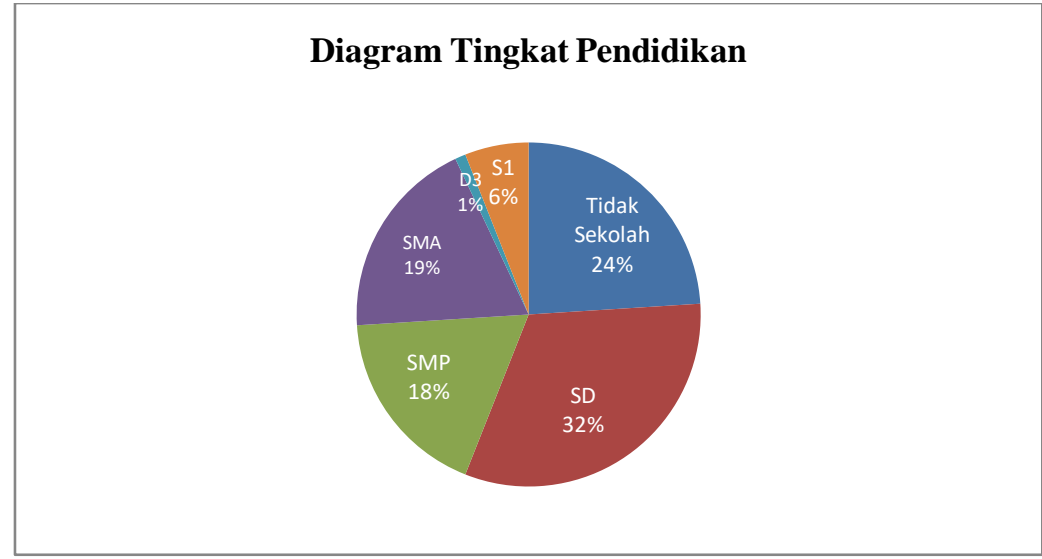

Sumber: Data primer setelah diolah.

Pada gambar 5,digambarkan tingkat pendidikan tenaga kerja di desa Ujung Bulu, 32\% tenaga kerja usaha tani hanya menempuh pendidikan sampai sekolah dasar.Tenaga kerja yang pernah menempuh pendidikan SMP sebanyak 18\% sementar tenaga kerja yang perna menempuh pendidikan SMA adalah $19 \%$. Selain itu terdapat pula tenaga kerja usaha tani yang pernah menempuh pendidikn di Perguruan Tinggi yaitu Diploma 3 (D3) sebanyak 1\% dan Strata satu (S1) sebanyak $6 \%$.

Tingkat pendidikan akan sangat berpengaruh pada proses usaha tani. Petani yang memiliki tingkat pendidikan yang lebih tinggi lebih memiliki kemapanan dalam berpikir dan mampu mengambil keputusan dengan tepat jika diperghadapkan dengan beberapa opsi yang ada.

Gambar 6.

Peta informasi spasial pendidikan petani kopi Desa Ujung Bulu.

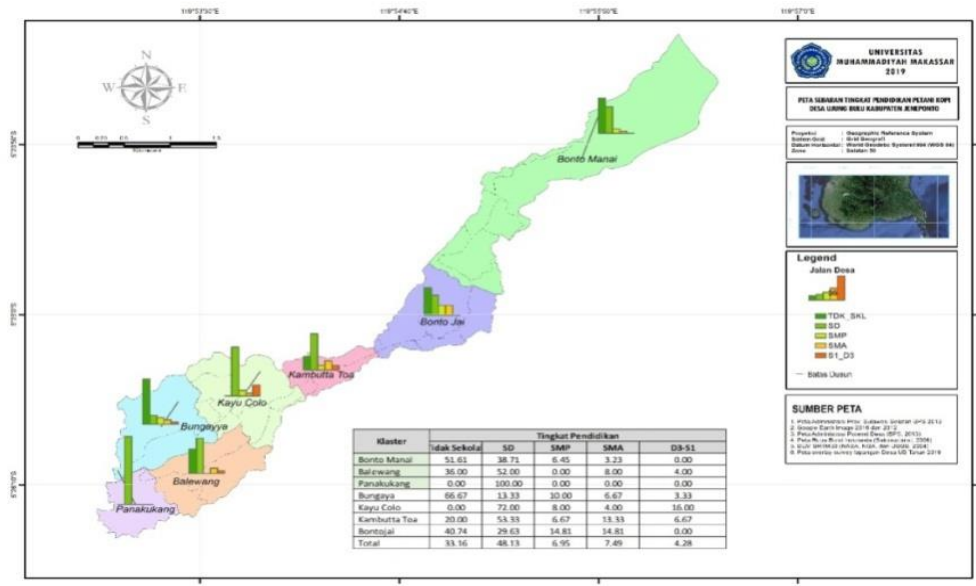


Pada peta informasi spasial diatas, digambarkan bagaimana sebaran tingkat pendidikan petani kopi pada setiap dusun di Desa Ujung Bulu, terlihat diatas bahwa tingkat pendidikan petani, didominasi oleh petani yang hanya menempuh pendidikan sampai sekolah dasar.Di Dusun Bonto Manai, Bonto Jai dan Bungaya kebanyakan petani tidak pernah menempuh jalur pendidikan formal. Sementara pada 4 dusun lainnya, yaitu Dusun Kambutta toa, Kayu Colo, Balewang dan Panakkukang sebagian besar petani adalah lulusan sekolah dasar. Hanya ada sebagian kecil petani yang menempuh pendidikan sampai SMP, SMA, dan SI/D3.

\section{Kesehatan}

Kesehatan merupakan faktor yang sangat penting dalam menunjang aktivitas sehari-hari, terkhusus pada masyarakat yang penduduknya bergerak di sektor pertanian.

Sebesar apa pun potensi sumberdaya alam suatu daerah jika masyarakatnya memilik tingkat keseshatan yang rendah maka daerah tersebut akan kesulitan dalam mengambangkan potensi daerahnya. Di desa Ujung Bulu' sendiri terdapat 2 penyakit yang sangat sering menyerang masyarakat yaitu flu dan demam seperti yang dimabarkan pada gambar berikut.

Gambar 7.

Penyakit yang sering diderita oleh masyarakat Desa Ujung Bulu.

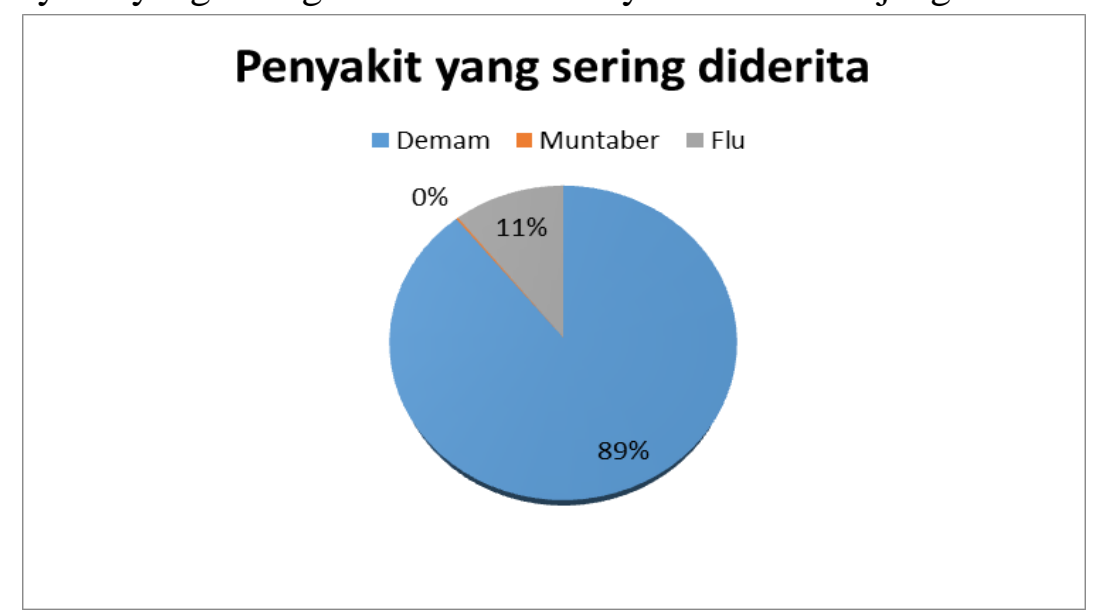

Sumber: Data primer setelah diolah.

Pada gambar 7 diatas terlihat jelas sebanyak 89\% warga Ujung Bulu sering terkena penyakit demam dan $11 \%$ lainnya sering terkena flu, menurut keterangan daeng Agus : 
"Penyakit yang sering dialami warga itu penyakit biasaji seperti flu sama demam, begitumi kalau di daerah dinginki tinggal”.

Untuk mengobati penyakit semacam flu dan demam masyarakat hanya mengkonsumsi obat yang di beli di warung karna pustu di Desa ini belum difungsikan sebagaimana mestinya, sementara kesehatan sangat berperan penting dalam menunjang aktivitas sehari-hari guna meningkatkan perekonomian masyarakat.

\section{Persepsi Kaum Muda}

Kaum muda memiliki peran dalam kelanjutan usaha tani dalam suatu daerah.Sehingga kelanjutan system pertanian suatu daerah dapat dilihat bagaimana persepsi kaum muda dalam menilai sektor pertanian itu sendiri sebagai suatu sumber mata pencaharian.Persepsi kaum muda di desa ujung bulu dapat di lihat dari gambar berikut.

Gambar 8 .

Persepsi Kaum Muda Desa Ujung Bulu.

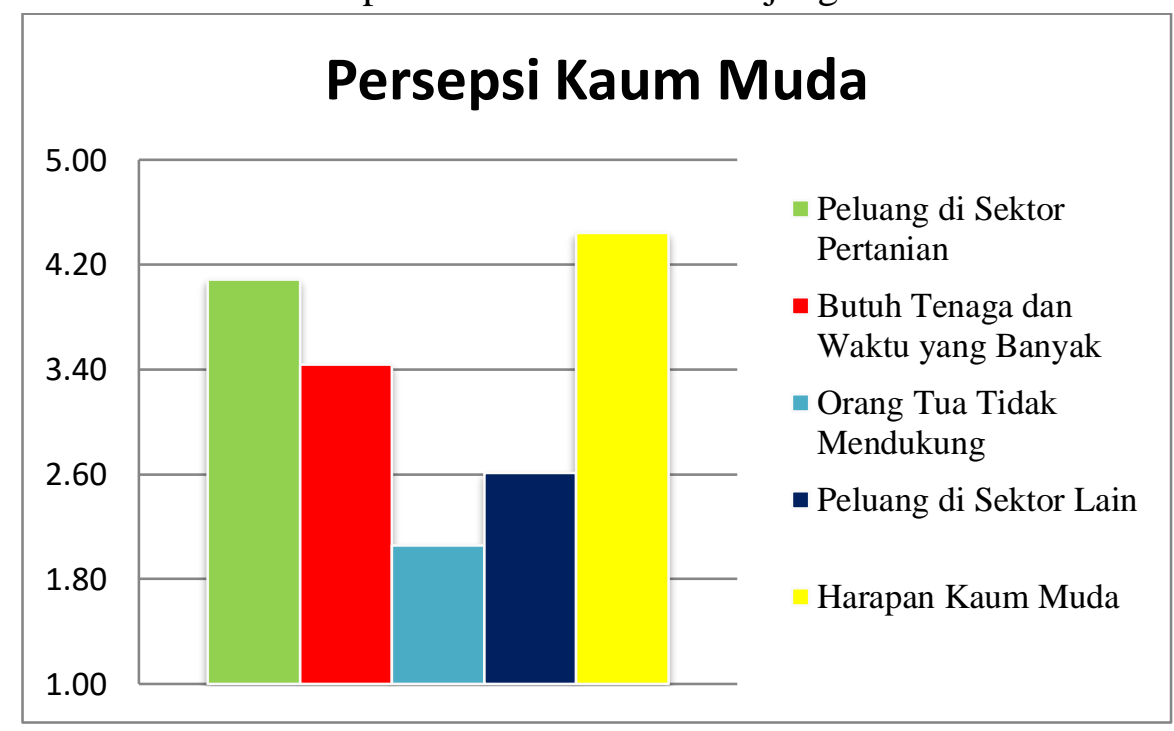

Sumber: Data primer setelah diolah.

Sebagian masyarakat Desa Ujung Bulu percaya bahwa bekerja disektor pertanian memiliki peluang lebih besar untuk menjamin pemenuhan kebutuhan ekonomi masyarakat dibandingkan dengan sektor lain walaupun menurut masyarakat bekerja di sektor pertanian membutuhkan waktu yang cukup lama dan tenaga yang besar. Tuk Sekalipin beberapa orang tua sudah tidak menginginkan 
lagi anaknya bekerja di sektor pertanian tetapi jumlahnya tidak banyak, sebagian besar orang tua masih menaruh harapan yang besar kepada anak kaum muda untuk melanjutkan usaha di sektor pertanian hal ini di sebabkan minimnya peluang masyarakat di Desa Ujung Bulu terutama pemuda untuk bekerja di sektor lain terkecuali jika mereka ingin merantau ke daerah lain

\section{PENUTUP/SIMPULAN}

Berdasarkan hasil penelitian dan pembahasan yang telah dilakukan, maka dapat ditarik kesimpulan sebagai berikut:

1. Adanya saling keterkaitan antara faktor sosial dan faktor ekonomi petani kopi di Desa Ujung Bulu. Faktor yang paling berpengaruh adalah umur petani seperti yang digambarkan pada peta informasi spasial (gambar 4)

2. Faktor yang memiliki pengaruh terbesar adalah Umur petani (gambar 4)

3. Dari gambar peta tersebut terlihat bahwa semakin tinggi tingkat sebaran petani usia produktif semakin tinggi pula hasil produksi yang dihasilkan.

4. Desa Ujung Bulu sangat ideal untuk pertumbuhan komoditi kopi sehingga sangat bagus dijadikan sebagai lokasi pengembangan tanaman kopi.

\section{DAFTAR PUSTAKA}

Affandi Rustam, dkk. (2017). Analisis Spasial Pelayanan Fasilitas Sosial Ekonomi Di Kelurahan Giripurwo. Jurnal Pengelolaan Sumberdaya Wilayah Berkelanjutan. 188-191.

Arifin, Bustanul. (2004). Refleksi dan Perkembangan Agribisnis di Indonesia. Jurnal Agrimedia, Institut Pertanian Bogor Vol.4. IPB. Bogor.

Badan Pusat Statistik (BPS). Jeneponto Dalam Angka 2017. Katalog BPS 1102001.1375 diakses dari http://www.bps.go.id/, diakses pada tanggal 17 Mei 2018 pada jam 19.37 WIB.

Damsar dan Indriani. (2009). Pengantar Sosiologi Ekonomi. PT. Kharisma Utama, Jakarta.

Fiendry Yusril. (2007). Analisis Spasial Penyebaran Fasilitas-Fasilitas Pelayanan dan Tingkat Efisiensi Pelayanan Desa. Skripsi. Bogor. Institut Pertanian Bogor. 
Isnam, Junais dkk. (2019). Integrasi pendekatan sosio-spasial dalam perencanaan penggunaan lahan untuk komoditas agribisnis: Studi Kasus kabupaten tertinggal di sulawesi selatan, Indonesia. 2-3.

Jayadinata, J,T. (1999). Tata Guna Tanah Dalam Perencanaan Pedesaan, Perkotaan dan Wilayah. Edisi ke-3. ITB. Bandung.

Krisbandono Adji dkk. (2015). Policy Brief: Pemetaan Sosial Ekonomi dan Lingkungan, Pusat Litbang dan Penerapan Teknologi dan Badan Litbang Kementrian Pekerjaan Umum dan Perumahan Rakyat. Jakarta.

Muh Sukriyanto AR. (2017). Faktor-Faktor Yang Mempengaruhi Tingkat Ketersediaan Sarana dan Prasarana Produksi dan Aksesibilitas Informasi Pertanian di Desa Ujung Bulu Kecamatan Rumbia Kabupaten Jeneponto.Skripsi.Makassar.Universitas Muhammadiyah Makassar.

Pemerintah Indonesia. (2013). Pedoman Pemetaan Sosial Ekonomi dan Lingkungan Bidang Pekerjaan Umum. Lembaran Negara RI Tahun 2013, No. 05. Sekretariat Negara. Jakarta.

Rudito, Bambang dan Melia Famiola. (2008). Social Mapping: Metode Pemetaan Sosial Teknik Memahami Suatu Masyarakat atau Komuniti. Bandung Rekayasa Sains.

Prayogo, Dody. (2003). "Pemetaan Sosial Mengenai Hubungan KorporasiKomunitas Lokal" dalam Masyarakat. Jurnal Sosiologi. Edisi No 12.Depok: Labsosio FISIP-UI.

Rahardjo, Pudji. (2012). Panduan Budidaya dan Pengolahan Kopi Arabika dan Robusta. Penebar Swadaya: Jakarta.

RPJM Desa Ujung Bulu. (2016). Rencana Pembangunan Jangka Menengah Tahun 2016-2021 Kabupaten Jeneponto.

Saepul Asep dan Baharuddin.E. (2014). Metode Penelitian Kuantitatif Apklikasi dalam Pendidikan. Deepublish. Daerah Istimewa Yogyakarta.

Saragih, Bungaran. (2001). Suara dari Bogor: Membangun Sistem Agribisnis. Yayasan USESE. Bogor.

Soekartawi. (1993). Agribisnis Teori dan Aplikasinya. Raja Garfindo Persada, Jakarta.

Spillane, J.J. (1990). Komoditi Kopi Peranannya Dalam perekonomian Indonesia. Kanisius, Yogyakarta.

Sugiyono. (2010). Metode Penelitian Pendidikan Pendekatan Kuantitatif, Kualitatif dan $R \& B$.Bandung: Alfabeta. 
Sugiyono. (2012). Metode Penelitian Kuantitatif Kualitatif dan R\&D. Bandung: Alfabeta.

Suharto, Edy. (2005). Membangun Masyarakat Memberdayakan Rakyat: Kajian Strategis Pembangunan Kesejahteraan Sosial dan Pekerjaan Sosial. Bandung: PT Refika Aditama.

Suriadi Andi. (2015). Pemetaan Sosial Ekonomi Dan Lingkungan Mendukung Pengembangan Kawasan Dan Konservasi Ekosistem Danau Tempe Sulawesi Selatan. Pusat Litbang dan Penerapan Teknologi dan Badan Litbang Kementrian Pekerjaan Umum dan Perumahan Rakyat. Jakarta. 